\title{
Expression, purification and molecular analysis of the human ZNF706 protein
}

\author{
Jucimara Colombo ${ }^{1 \dagger}$, Paola Jocelan Scarin Provazzi ${ }^{1 \dagger}$, Marilia Freitas Calmon ${ }^{1}$, Lilian Campos Pires ${ }^{1}$, \\ Nathália Campos Rodrigues², Paulo Petl $\mathrm{Jr}^{1}$, Marcelo Andrés Fossey ${ }^{3}$, Fátima Pereira de Souza ${ }^{3}$, \\ Fernanda Canduri ${ }^{2}$ and Paula Rahal ${ }^{1 *}$
}

\begin{abstract}
Background: The ZNF706 gene encodes a protein that belongs to the zinc finger family of proteins and was found to be highly expressed in laryngeal cancer, making the structure and function of ZNF706 worthy of investigation. In this study, we expressed and purified recombinant human ZNF706 that was suitable for structural analysis in Escherichia coli BL21(DH3).

Findings: ZNF706 mRNA was extracted from a larynx tissue sample, and cDNA was ligated into a cloning vector using the TOPO method. ZNF706 protein was expressed according to the E. coli expression system procedures and was purified using a nickel-affinity column. The structural qualities of recombinant ZNF706 and quantification alpha, beta sheet, and other structures were obtained by spectroscopy of circular dichroism. ZNF706's structural modeling showed that it is composed of a-helices (28.3\%), $\beta$-strands (19.4\%), and turns (20.9\%), in agreement with the spectral data from the dichroism analysis.

Conclusions: We used circular dichroism and molecular modeling to examine the structure of ZNF706. The results suggest that human recombinant ZNF706 keeps its secondary structures and is appropriate for functional and structural studies. The method of expressing ZNF706 protein used in this study can be used to direct various functional and structural studies that will contribute to the understanding of its function as well as its relationship with other biological molecules and its putative role in carcinogenesis.
\end{abstract}

Keywords: Circular dichroism, Cloning, HSPC038, Molecular modeling, Protein expression, ZNF706 protein

\section{Background}

The ZNF706 gene encodes a protein that belongs to the zinc finger family of proteins. Zinc finger proteins are involving in endogenous gene expression control by binding to specific DNA sequences [1]. Zinc finger-containing transcriptional factors have previously been shown to participate in the MAPK signaling pathway regulation. These factors are among the principal methods of gene expression regulation on eukaryotic cells [2]. Moreover, the ZNF706 gene was associated with the Epidermal Growth Factor (EGF) to control the cell volume via the ICln gene [3]. ZNF proteins are now known to have additional activities such as the recognition of RNA and other proteins [4].

\footnotetext{
* Correspondence: rahalp@yahoo.com.br

'Equal contributors

'Department of Biology, São Paulo State University - UNESP, CEP: 15054-000, São José do Rio Preto/SP, Brazil

Full list of author information is available at the end of the article
}

Despite the little information available about the biological functions of ZNF genes [5], some were indicated as participant in diseases or gene expression control. The transcriptional activity of activator protein 1 (AP1) was found to be enhanced by the ZNF445 gene [6]. The ZNF674, ZNF41 and its homologous ZNF81 are three X chromosome ZNF genes located in Xp11 and were associated with non-specific X-linked mental retardation $[7,8]$. The ZNF743 protein was found to be associated with methyl-CpG-binding protein 2 (MBD2) and was implicated in transcriptional and epigenetic controls [7].

The ZNF706 gene, which is located at $8 \mathrm{q} 22.3$, is a zinc finger gene family member. Currently, there are no studies that describe the more specific functions of this gene. However, it was observed that ZNF706 gene has a sex-specific gene expression pattern in human lymphoblastoid cell lines [8], and was found to be highly expressed in laryngeal

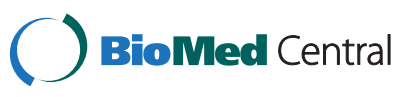


cancer [9]. Likewise, copy number amplifications on chromosome 8 in cancer gastric samples were identified [10]. The gained regions detected in at least $25 \%$ of the samples were located at 8p11-q24 [10]. In addition, the ZNF706 gene was concordantly up-regulation in the analyzed gastric cancer samples [10]. High expression of the ZNF133 gene was also verified in head and neck cancer [11]. However, low expression of other zinc finger family members, such as ZNF185 [12,13], ZNF212 [14], ZNF262 [14] and ZNF273 [15] has already been observed in head and neck cancer. Thus, the zinc finger family genes can operate as enhancers or repressors of gene expression; depending on their action, they may have high or low expression levels in neoplastic tissues.

Structurally, the zinc finger proteins can be classified from the number and type of amino acids associated in zinc ion binding site, like the $\mathrm{C}_{2} \mathrm{H}_{2}, \mathrm{C}_{2} \mathrm{HC}, \mathrm{C}_{4}$ ribbon, $\mathrm{C}_{4}$ GATA, $\mathrm{C}_{6}, \mathrm{C}_{8}, \mathrm{C}_{3} \mathrm{HC}_{4}$ ring finger and $\mathrm{H}_{2} \mathrm{C}_{2}$. The $\mathrm{C}_{2} \mathrm{H}_{2}$-type zinc finger proteins (of which ZNF706 is a member) have the most common DNA binding site and correspond to approximately $30 \%$ of all transcription factors in the human genome $[16,17]$. The $\mathrm{C}_{2} \mathrm{H}_{2}$-type zinc fingers fold into a $\beta \beta \alpha$ structure with the support of the zinc ion. Each finger typically recognizes 3-4 base pairs of DNA [17].

ZNF706 protein has 76 amino acids; however, no information on ZNF706 protein structure and function is available in the literature. In this work, we expressed, using a eukaryotic system, and purified the recombinant human ZNF706 human protein for structural analysis by molecular modeling and circular dichroism. Structural characterization may aid the study of the specific interactions of ZNF706 with other biological molecules such as inhibitors. This will contribute to the understanding of the specific function of ZNF706 and its putative role in carcinogenesis and to the design of new drugs.

\section{Results}

ZNF706 mRNA was extracted from a larynx tissue sample and cDNA was ligated into a cloning vector using the TOPO method (Invitrogen, Grand Island, NY, USA). Amplification of ZNF706 cDNA produced a fragment of approximately 262 bp (Figure 1A). After the cloning of this PCR product into the pET101 expression vector, five clones were verified using specific primers from the TOPO kit (Invitrogen, Grand Island, NY, USA). The PCR product was approximately 262 bp long (Figure 1B). Sequencing verified the identity of the sequence and the fidelity of cloning in clones 1 and 3 (data not shown).

Selected clones were transformed into E. coli BL21 (DE3) competent cells and the protein expression was performed using the $\mathrm{T} 7$ system after induction with IPTG 1.5 mM IPTG (Sigma, St. Louis, MO, USA) for 16 hours.

The SDS-PAGE electrophoresis showed the ZNF706 protein expression in a soluble fraction with a molecular weight of $12 \mathrm{kDa}$ as determined by Coomassie Brilliant reagent (BIO-RAD, Hercules, CA, USA) (Figure 2). The protein was purified on a nickel-resin column (BIORAD, Hercules, CA, USA), and the fractions of ZNF706 protein could be visualized (Figure 3). ZNF706 protein has 76 amino acids and is $8.49 \mathrm{kDa}$ in size. However, because the heterologous protein has a $6 \mathrm{xHis}$ tag and one start codon, the observed size is $12 \mathrm{kDa}$.

After purification, the ZNF706 protein fractions were concentrated using an Amicon ultrafiltration cell system (MWC 3,000 Da) (Millipore, Billerica, MA, USA) (Figure 4). The ZNF706 concentration (3.0 mg) was obtained using the absorbance reading at $280 \mathrm{~nm}$.

The secondary structure content of ZNF706 was verified by CD spectroscopy (Figure 5). The CD spectrum showed that the protein contained a higher quantity of $\alpha$-helical structures with a minimum ellipticity at 205 $\mathrm{nm}$ and at $222 \mathrm{~nm}$. The secondary structure indicated by CDPro suite of the CD spectrum [18] shows that the protein is composed of $\alpha$-helices (35\%), $\beta$-strands (10\%), turns (27\%) and random coils (28\%). The results obtained are in agreement with the expected structure for zinc finger proteins.

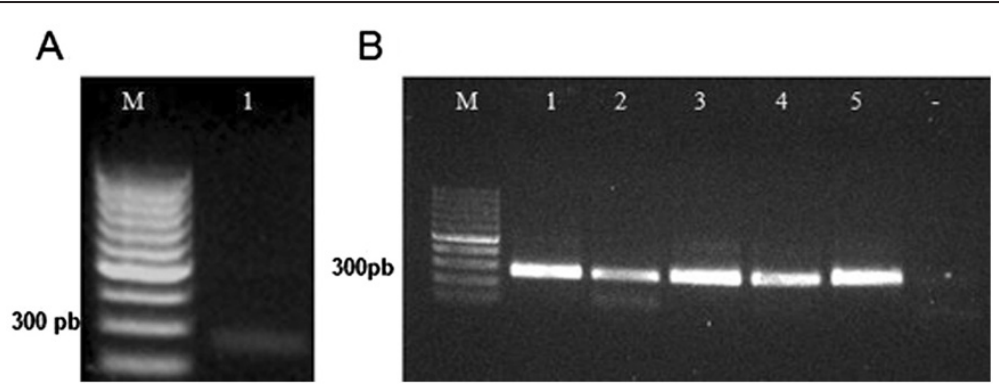

Figure 1 Amplification of ZNF706 gene. A) Agarose gel shows RT-PCR of the ZNF706 gene. Lane M: molecular weight marker (Invitrogen, Grand Island, NY, USA); Lane 1: amplification of ZNF706 gene (262 bp). B) Agarose gel shows amplification of the ZNF706 gene cloned into pET101 expression vector in 5 plasmid preparations. 


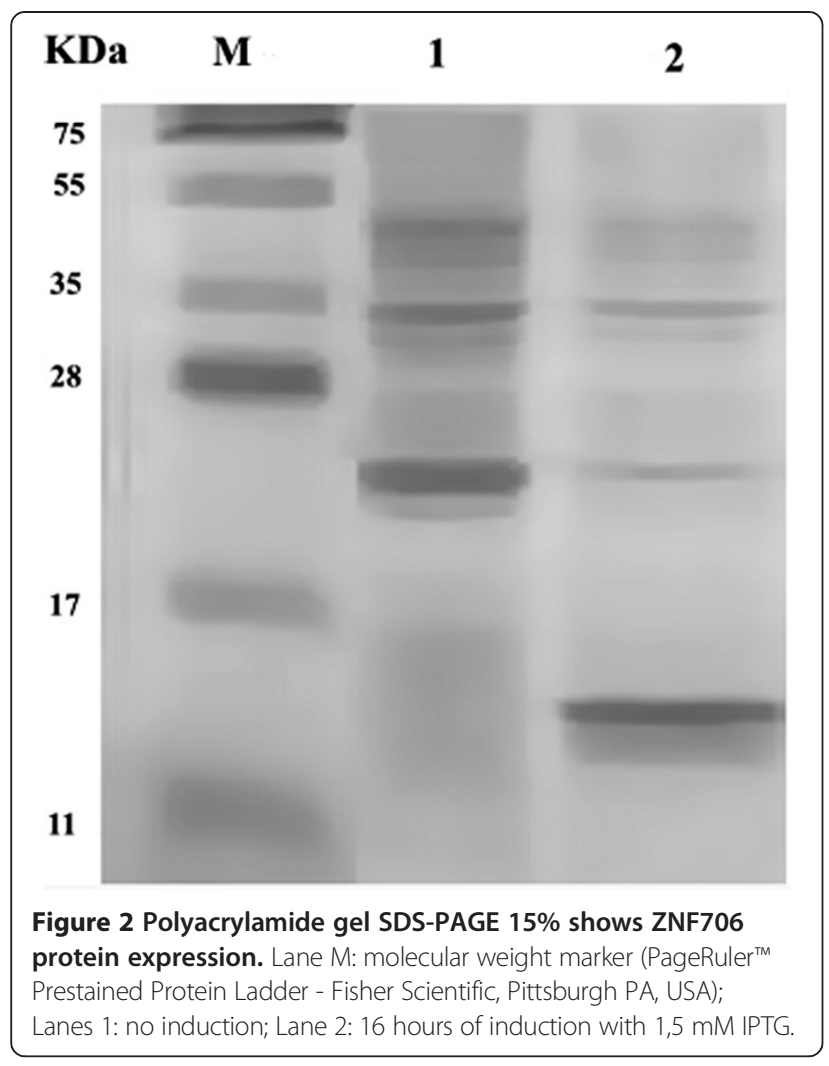

The sequence alignment between HsZNF706 and the zinc-finger region of human Zinc- Fingers and Homeoboxes 1 (ZHX1) (PDB code 2GHF) showed 34.1\% identity, with 41 amino acids aligned. HsZNF706 has 76 amino acid residues in the sequence, and the $2 \mathrm{GHF}$ template has 102 residues. Nine residues from the Nterminus of the target were removed. The structure generated by homology modeling $[19,20]$ had an RMSD of 1.095 compared to the template; this estimate takes into account the $\mathrm{C} \alpha$ from the 65 superimposed residues (Figure 6). The global stereochemical quality [21] of the HsZNF706 protein model indicated that 98.3\% of the amino acids were in the most allowed and additional allowed regions, with only $1.7 \%$ (Lys55) in the disallowed region. Structural analysis showed that the side chain of Lys55 is in contact with the solvent in a superficial conformation. The Procheck software [21] was used to calculate the G-factor average value and set to be -0.1 . The Verify-3D [22] software analysis, revealed that $32.4 \%$ of the amino acids had an average value $3 \mathrm{D}$ - $1 \mathrm{D}$ score of $>0.2$, showing some compatibility with the HsZNF706 model. Fifty percent of the amino acids in the template had an average value 3D-1D score of $>0.2$.

The HsZNF706 model consists of $\alpha$-helices (28.3\%), $\beta$-strands (19.4\%) and turns (20.9\%), compared to $25.8 \%$, $16.1 \%$ and $20.4 \%$, respectively, for the template. The

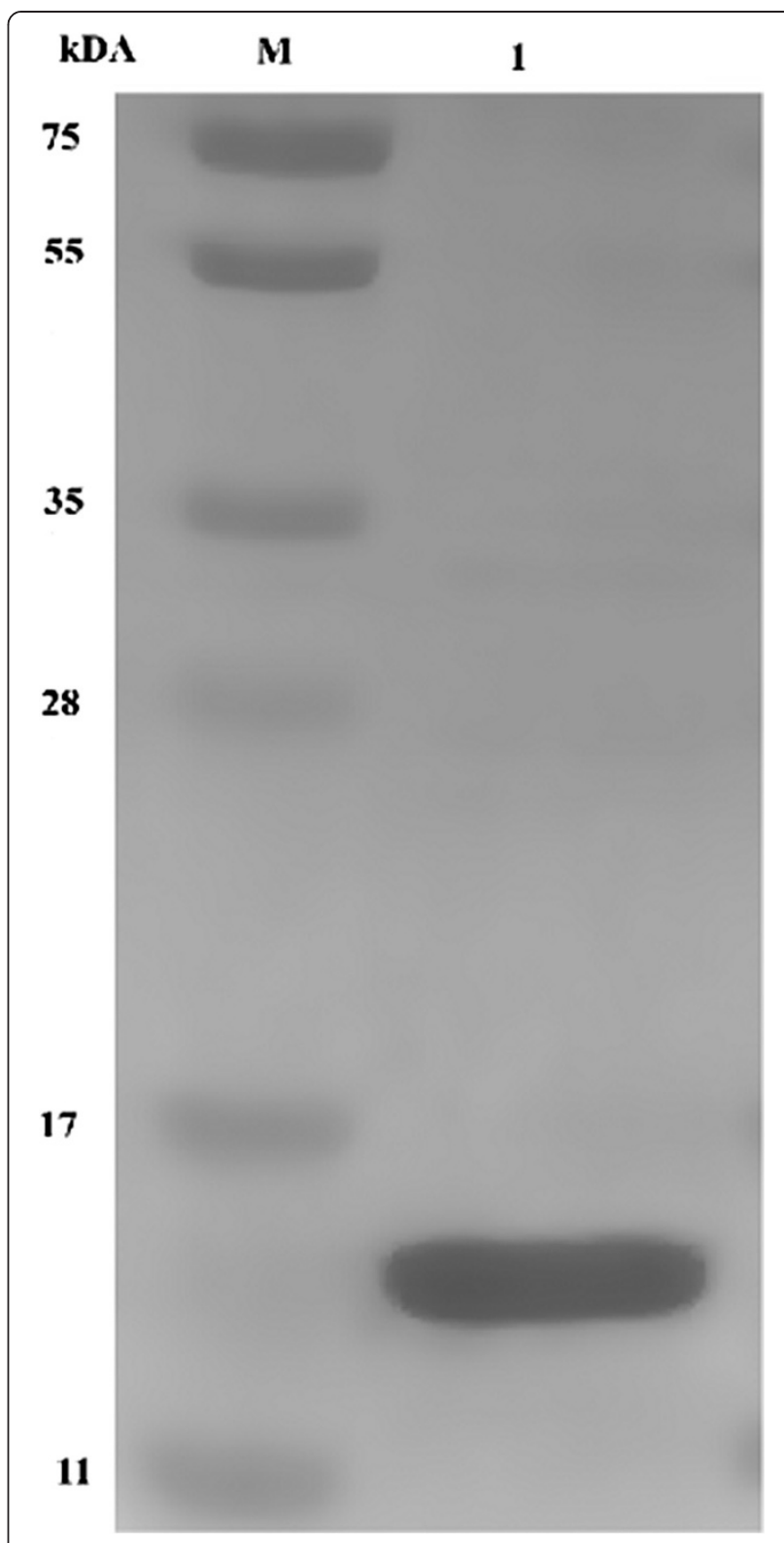

Figure 3 Polyacrylamide gel SDS-PAGE 15\% shows ZNF706 protein after purification and concentration procedures. Line $M$ : molecular weight marker (PageRuler ${ }^{\mathrm{TM}}$ Prestained Protein Ladder Fisher Scientific, Pittsburgh PA, USA); Line 1: ZNF706 protein.

structure is dominated by metal-ligand, heme and/or disulfide bridges, like other members of this small protein class, and is arranged in a $\beta-\beta-\alpha$ zinc finger fold. This model includes a simple fold consisting of the $\mathrm{N}$-terminal $\beta$-hairpin and $C$-terminal $\alpha$-helical region; each part provides two zinc-coordinating residues. Using the partial structural model of HsZNF706, the binding sites of the zinc ion were determined (Figure 7). The first ion is near the $\mathrm{N}$-terminal $\beta$-hairpin in a site formed mainly 


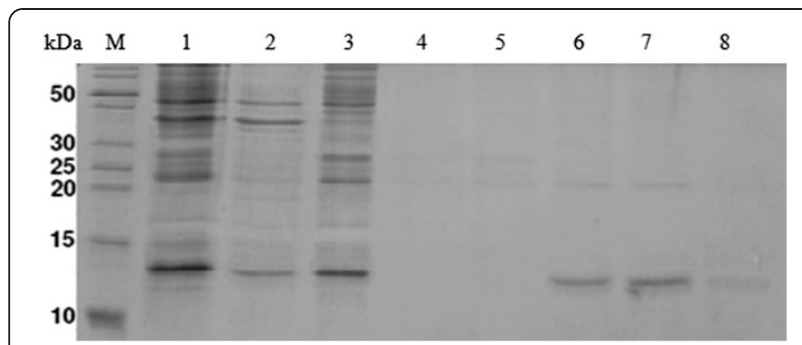

Figure 4 Polyacrylamide gel SDS-PAGE $18 \%$ shows purification of the recombinant human ZNF706 protein by nickel-affinity chromatography. Lane M: molecular weight marker (PageRuler ${ }^{\mathrm{TM}}$ Unstained Protein Ladder - Fisher Scientific, Pittsburgh PA, USA); Lane 1: crude extract. Lane 2: insoluble fraction. Lane 3: soluble fraction. Lane 4: Column washed with buffer plus imidazole $10 \mathrm{mM}$. Lane 5. Column washed with buffer plus imidazole $20 \mathrm{mM}$. Lanes 6-7. ZNF706 protein elution with buffer plus imidazole $250 \mathrm{mM}$. Lane 8: ZNF706 protein elution with buffer plus imidazole 500 mM.

by neutral and hydrophobic residues, and the second ion is near the second $\beta$-hairpin and C-terminal $\alpha$-helix (Figure 7) at 2.9 Angstroms from the Q56 side chain and 2.7 Angstroms from the E70 side chain.

The generated model presents two cysteine residues next to each other in the tridimensional conformation (Cys41 and Cys44), but not involved in a disulfide bridge due to the distance between them (the distances of two bonded sulfur atoms is known to be distributed between $1.8-2.0 \AA$ with a highest frequency at about $2.0 \AA$ in proteins, and the distance between the sulfur atoms in the model is more than $3 \AA$ ). The model has a conserved folding module in ZNFs, which is the most probable folding obtained. The crystallographic structure will confirm these data. The $\mathrm{N}$-terminal 9 residues of the target were not considered in this prediction because they are not reflected in the template and can be considered a characteristic region of HsZNF706.

\section{Discussion}

Zinc finger (ZNF) proteins play critical roles in cell growth, proliferation, apoptosis, and intracellular signal transduction [23]. The ZNF706 gene cDNA is 2755 bp in length and encodes a putative protein of 76 amino acid residues. However, the function and structure of the ZNF706 protein were uncharacterized. The results presented here show that recombinant ZNF706 gene was cloned and the protein was expressed in E. coli bacteria cell line and purified from the soluble fraction in a single procedure step.

In this work, we used circular dichroism and molecular modeling to examining the structure of ZNF706. Circular dichroism (CD) spectroscopy is an important methodology used in structural biology for quantifying secondary structure content, conformational changes due to drug binding, folding, interactions involving protein molecules and protein quality [24]. Our results suggest that human recombinant ZNF706 keeps its secondary structures and is able to perform functional and structural studies. The agreement between the secondary structures predicted by molecular modeling and the secondary structure obtained by $(\mathrm{CD})$ spectroscopy increases our confidence in the accuracy of the ZNF706 model. However, the N-terminal region of ZNF706 protein could not be resolved because there is no suitable template deposited in public databases. This region may be unique to the ZNF706 protein and therefore needs to be resolved. This problem reinforces the need for

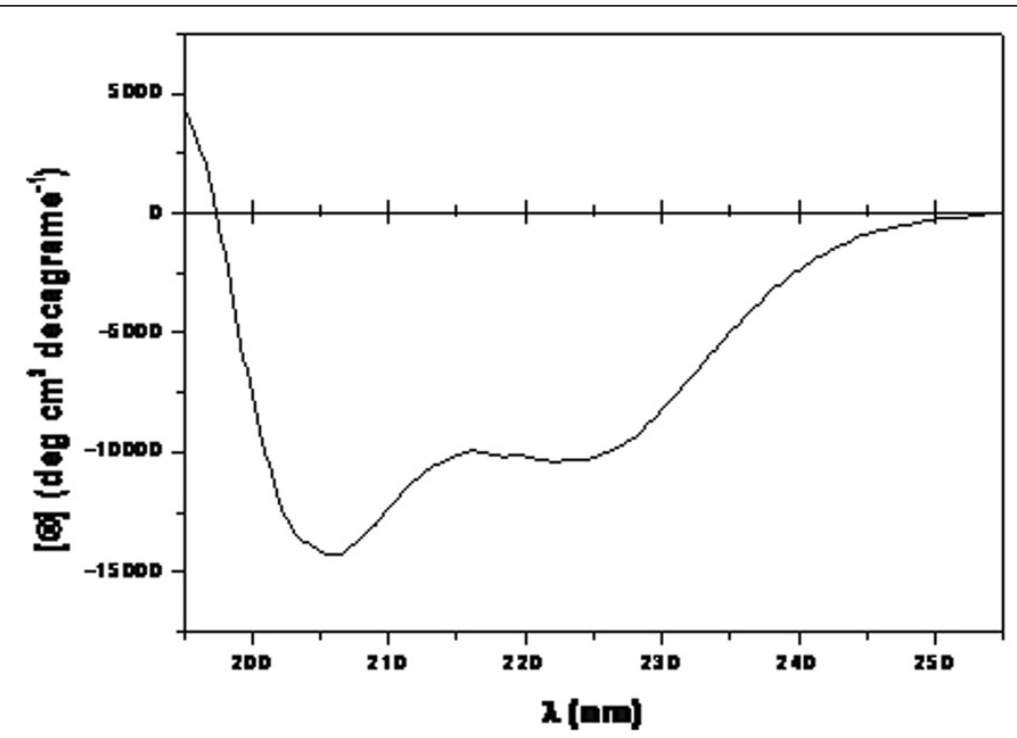

Figure 5 Analysis of ZNF706 secondary structure by CD spectroscopy. The CD spectrum of ZNF706 was acquired in $300 \mathrm{mM}$ sodium phosphate, $\mathrm{pH} 8.0$, at a concentration of $3,0 \mathrm{mg} / \mathrm{ml}$. 


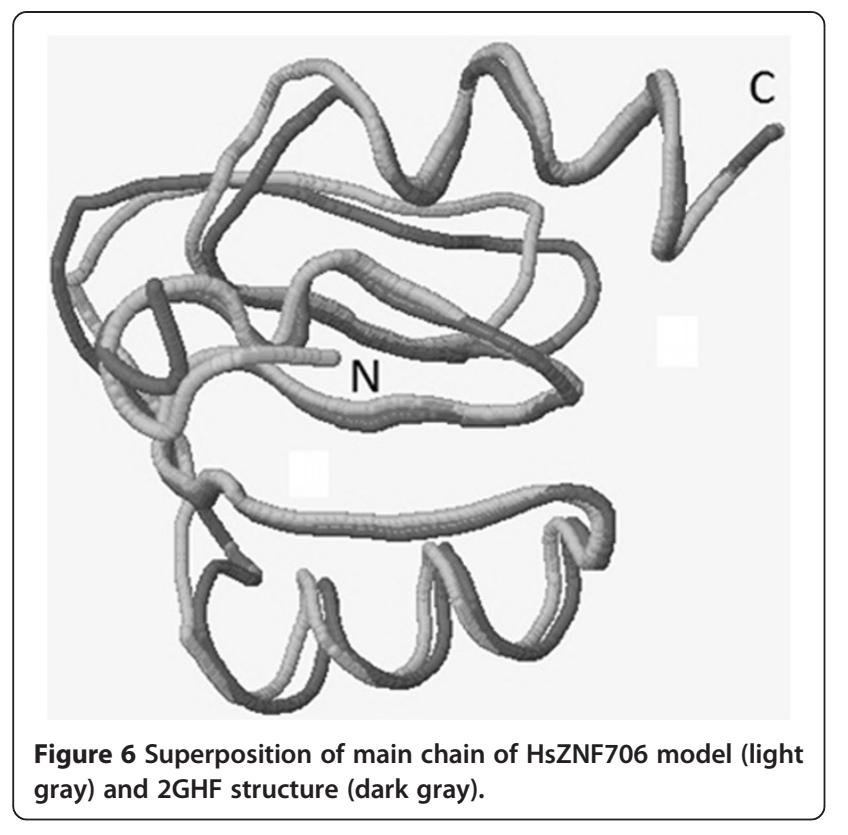

experimental structural studies involving techniques such as crystallography to solve the structure of the $\mathrm{N}$-terminal region of this protein. Moreover, experimental determination of the three-dimensional structure will contribute to investigations of interactions of ZNF706 with ligands.

The knowledge of the Human ZNF706 protein structure is important for understanding the mechanisms of its interactions with other molecules and allowing structure-aided drug design $[25,26]$. The interaction between DNA target sequence and the zinc-finger proteins motivated the design of specific zinc finger peptides that

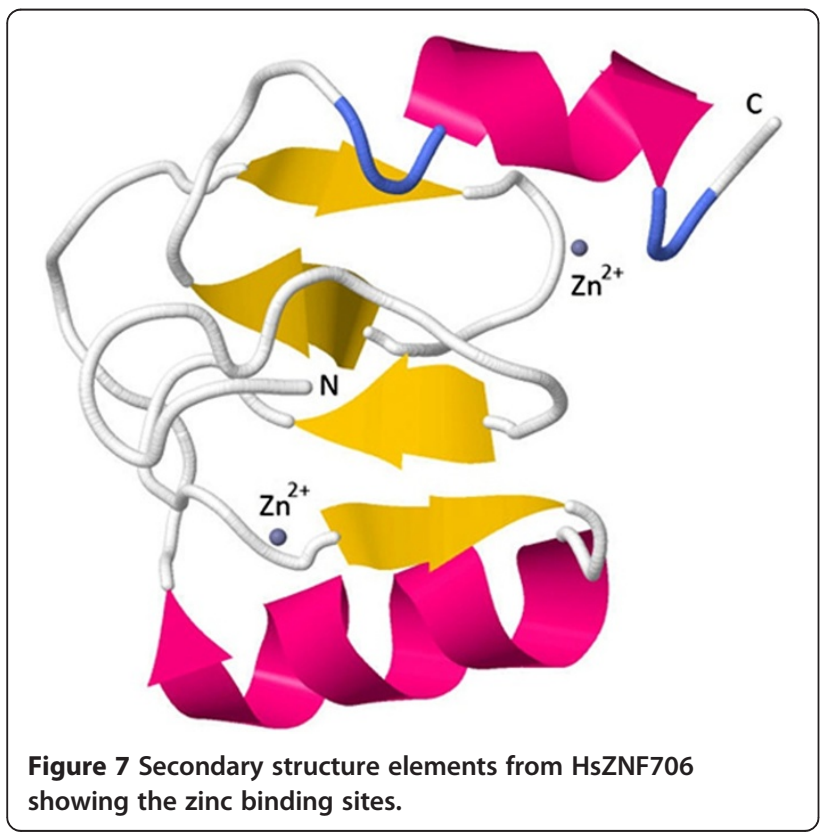

can be used for medical and biochemical interaction studies $[27,28]$.

An example of the application of these custom zinc finger proteins involves several kinds of methyltransferases, which have been linked to zinc-finger motifs and analyzed in vitro and in vivo conditions. This targeted DNA methylation allows artificial gene silencing and can be used to prevent an overexpressed gene in cancer by adding a methyl group to the target gene. Targeted DNA methylation was demonstrated to be effective at repressing Herpes Simples Virus type I (HSV-1) infection in cell culture [29]. Several groups have tested zinc fingers to inhibit the replication of integrated HIV $[30,31]$ and high-risk HPV type 18, which is involved in cervical cancer [32]. Thus, custom zinc finger proteins can be engineered to control the expressions of target genes and have therapeutic potential for the study and treatment of diseases. Moreover, with further advances in zinc finger protein research, it may become possible to construct synthetic cell networks and control high-level vital functions [17].

The ZNF706 protein structural data obtained in this work by circular dichroism and molecular modeling can contribute to the understanding of the protein's function, the relationships to other biological molecules and its possible role in carcinogenesis. Moreover, it represents the first step towards a future customized ZNF706 peptide that could act on cellular signaling networks and establishes the relationship between ZNF706 and diseases such as cancer.

\section{Conclusion}

In this work, we used circular dichroism and molecular modeling to examine the structure of ZNF706. Our results suggest that recombinant human ZNF706 keeps its secondary structure and is appropriate for functional and structural studies. The agreement between the secondary structures predicted by molecular modeling and the secondary structure obtained by $(\mathrm{CD})$ spectroscopy increases our confidence in the accuracy of the ZNF706 model. The data obtained in this work can contribute to the understanding of the protein's function, relationships to other biological molecules and its possible role in carcinogenesis allowing structure-aided drug design. Moreover, it represents the first step towards a future customized ZNF706 peptide that could act on cellular signaling networks and establishing the relationship between ZNF706 and diseases such as cancer.

\section{Methods}

Reverse transcription reaction and ZNF706 CDNA cloning For the Reverse Transcription (RT-PCR) procedure, total RNA was extracted from larynx tumor tissue samples using Trizol reagent (Invitrogen). The full-length ZNF706 cDNA was performed using the following 
oligonucleotide primers: Forward, CATCACCATCA GATGGCTCGTGGACAG; Adapt F, CACCATGAA ACATCATCACCATCACCATCAG and Reverse, TT ATGCCTGAACATCAGCTA, which were constructed using the GenBank ZNF706 cDNA sequence No. NM_016096.3 as the reference. The N-terminal polyhistidine tag used for recombinant protein purification is shown in bold. The protease recognition site for removal of the $\mathrm{N}$-terminal polyhistidine tag is shown in italics. The nucleotides CACC are the overhang sequence for binding to pET101 (Invitrogen).

The ZNF706 cDNA (231 bp) was amplified using the constructed set of primers and standard PCR conditions with Elongase (Invitrogen). After checking the amplification on an agarose gel, nested PCR with the product from the first PCR and Adapt F and Reverse primers was performed using the same amplification conditions. The amplification products were checked on an agarose gel and consisted of a specific band of approximately $262 \mathrm{bp}$, corresponding to the expected size of the ZNF706 gene (231 bp) plus the $31 \mathrm{bp}$ of the Adapt F primer.

\section{Subcloning in E. coli TOP10}

After purification with the Qiagen Purification Kit, the amplified fragment was inserted into the pET101 expression vector following the Championg pET Directional TOPO Expression Kit manufacturer's instructions (Invitrogen). pET101::ZNF706 was transformed into E. coli DH5alpha competent cells. Several colonies were collected from Luria-Bertani (LB) plates supplemented with ampicillin $(50 \mu \mathrm{g} / \mathrm{ml})$ and then inoculated into $5 \mathrm{ml}$ of LB medium containing ampicillin $(50 \mu \mathrm{g} / \mathrm{ml})$. The culture was incubated for 16 hours at $37^{\circ} \mathrm{C}$. Recombinant plasmid was extracted with a PureLink plasmid mini prep kit (Invitrogen). The fidelity of the cloned product was verified by sequencing using the specific primers provided in the TOPO kit.

\section{ZNF706 protein expression}

The expression plasmids pET101::znf706 were transformed into E. coli BL21(DE3) competent cells. After selection on LB agar plates (ampicillin - $50 \mu \mathrm{g} / \mathrm{mL}$ ), recombinant colonies were inoculated into $5 \mathrm{~mL}$ of $\mathrm{LB}$ medium supplemented with ampicillin $(50 \mu \mathrm{g} / \mathrm{mL})$. To test the optimal condition for ZNF706 protein expression, E. coli BL21 (DE3) cells carrying pET101::znf706 were grown in the presence of IPTG (isopropyl $\beta$-D-thiogalactoside) at different concentrations: $1.5 \mathrm{mM}, 1.0 \mathrm{mM}, 0.75 \mathrm{mM}$ and $0.5 \mathrm{mM}$. After centrifugation, the cells were re-suspended in lysis buffer containing $100 \mathrm{mM} \mathrm{NaCl}, 10 \mathrm{mM}$ Tris and $50 \mathrm{mM} \mathrm{NaH}{ }_{2} \mathrm{PO}_{4}$, at $\mathrm{pH}$ 8.0) and disrupted by sonication (eight short bursts of $15 \mathrm{~s}$ ). The proteins were separated by
SDS-PAGE electrophoresis and the bands were visualized using Coomassie Blue reagent.

\section{Large scale expression and purification}

A total of $20 \mathrm{~mL}$ of LB cell culture containing the recombinant plasmid was diluted in $2 \mathrm{~L}$ of LB supplemented with ampicillin $(50 \mu \mathrm{g} / \mathrm{mL})$. The culture was incubated at $37^{\circ} \mathrm{C}$ and $240 \mathrm{rpm}$ until the cells achieve $\mathrm{OD}_{600}=0.6$. At this point, the ZNF706 expression was induced with $1.5 \mathrm{mM}$ of IPTG following incubation at $37^{\circ} \mathrm{C}$ for 16 hours. The culture cell was submitted to centrifugation and the harvested cells were re-suspended in $20 \mathrm{~mL}$ of lysis buffer $(100 \mathrm{mM} \mathrm{NaCl}, 10$ $\mathrm{mM}$ Tris and $50 \mathrm{mM} \mathrm{NaH} \mathrm{PO}_{4}, \mathrm{pH}$ 8.0). To lyse the cells, the samples were incubated on ice with lysozyme $(0.5 \mathrm{mg} / \mathrm{mL})$ for $30 \mathrm{~min}$. After sonication (eight short bursts, with $15 \mathrm{~s}$ ) the lysate was submitted to centrifugation for $30 \mathrm{~min}$ at $14,000 \mathrm{rpm}$ and $4{ }^{\circ} \mathrm{C}$. The supernatant was loaded onto a nickel-affinity column (BIO-RAD; Profinity $^{\text {mix }}$ IMAC Ni-Charged Resin; $4 \mathrm{~mL}$ ) preequilibrated with purification buffer containing $50 \mathrm{mM}$ $\mathrm{NaH}_{2} \mathrm{PO}_{4}$ and $300 \mathrm{mM} \mathrm{NaCl}$, at pH 8.0. After washing, bound proteins were eluted with an imidazol gradient $(20 \mathrm{mM}, 50 \mathrm{mM}, 250 \mathrm{mM}$ and $500 \mathrm{mM}$ imidazol in purification buffer). Fractions containing ZNF706 were pooled, concentrated and dialyzed using an Amicon ultrafiltration cell (MWC 3,000 Da). The protein was analyzed by SDS-PAGE electrophoresis and visualized using Coomassie Brilliant Blue reagent.

The recombinant ZNF706 quantification was obtained by direct absorbance readings at $280 \mathrm{~nm}$.

\section{Circular dichroism}

Circular dichroism (CD) spectroscopy was realized in a Jasco 710 spectropolarimeter at $25^{\circ} \mathrm{C}$. The $\mathrm{CD}$ spectra was measured with a protein concentration of $3.0 \mathrm{mg} /$ $\mathrm{mL}$ in phosphate buffer $\mathrm{pH} 8.0,(300 \mathrm{mM})$, using a 0.05 $\mathrm{mm}$ optical length. The spectra were collected from 195 to $255 \mathrm{~nm}$. The results were converted to $\mathrm{mg} / \mathrm{ml}$ ellipticity units, $[\Phi]$ (deg cm2 decagram-1), and the alpha, beta sheet, and other structures were verified using CDPro software package [18].

\section{Molecular modeling}

The program MODELLER 9v8 was used to model the HsZNF706 structure. This program is an automated approach for homology or comparative modeling by satisfaction of spatial restraints $[19,20]$. The molecular modeling methodology began with the alignment of the target protein to be determined (HsZNF706) with the templates (related known three-dimensional protein structures). The template was a human Zinc fingers and homeoboxes protein 1 (ZHX1) (PDB code 2GHF) solved by Nuclear Magnetic Resonance (NMR), which has 
$34.1 \%$ identity and an overlap of 41 amino acids with the HsZNF706 sequence. The alignment among the amino acid sequence was the input of the software and a threedimensional model of the target protein sequence was the output. The energy terms and spatial restraints enforcing proper stereochemistry [33] were combined into an objective function. The resulting ZNF protein models were generated by optimization of the objective function in a Cartesian coordinate system. The optimization was performed with the variable target function method [34] by employing method of conjugate gradients and simulated annealing. A total of 300 models were obtained, and the final model was selected based on the stereochemical quality.

The overall stereochemical quality of the HsZNF706 model was based on the following analyses: 1) a Ramachadram plot obtained using the program PROCHECK $[21], 2)$ the rmsd from the distance of secondary structure alignment calculated using PDBeFold [http://www.ebi.ac.uk/msd-srv/ssm/], 3) the G-factor value calculated for the torsion angles (phi-psi, chi1-chi2, chi-1, chi-3, chi-4 and omega values for each amino acid residue) and covalent geometry (for the main-chain bond lengths and bond angles; calculated using PROCHECK) [21] and 4) the compatibility of the protein model with its sequence, calculated using Verify -3D software and a three-dimensional profile [22].

\section{Abbreviations \\ ZNF706: Zinc finger 706; LB: Luria-bertani medium; CD: Circular dichroism; NMR: Nuclear magnetic resonance; RMSD: Root mean square deviation; PDB: Protein data bank; RT-PCR: Reverse transcriptase-polymerase chain reaction.}

\section{Competing interests}

The authors have no conflict of interest.

\section{Authors' contributions}

Experiments were performed by JC, PJSP, LCP, NCR, PP, MF and FPS. JC, PJSP, MFC, FC, PFS and PR wrote and edited the text and all approved the final manuscript.

\section{Acknowledgments}

We thank the Fundação de Amparo à Pesquisa do Estado de São Paulo (FAPESP) for their financial assistance.

\section{Author details}

${ }^{1}$ Department of Biology, São Paulo State University - UNESP, CEP: 15054-000, São José do Rio Preto /SP, Brazil. " Institute of Chemistry of São Carlos, Department of Chemistry and Molecular Physics, University of São Paulo USP, CEP: 13560-970, São Carlos /SP, Brazil. ${ }^{3}$ Department of Physics, São Paulo State University - UNESP, CEP: 15054-000, São José do Rio Preto /SP, Brazil.

Received: 24 June 2013 Accepted: 14 September 2013 Published: 23 September 2013

\section{References}

1. Xiang Z, Yuan W, Luo N, Wang Y, Tan K, Deng Y, Zhou X, Zhu C, Li Y, Liu M, Wu X: A novel human zinc finger protein ZNF540 interacts with MVP and inhibits transcriptional activities of the ERK signal pathway. Biochem Biophys Res Commun 2006, 347:288-296.

2. Zhao Y, Zhou L, Liu B, Deng Y, Wang Y, Huang W, Yuan W, Wang Z, Zhu C, Liu M, et al: ZNF325, a novel human zinc finger protein with a RBaK-like
RB-binding domain, inhibits AP-1- and SRE-mediated transcriptional activity. Biochem Biophys Res Commun 2006, 346:1191-1199.

3. Tamma G, Dossena S, Nofziger C, Valenti G, Svelto M, Paulmichl M: EGF stimulates IClswell by a redistribution of proteins involved in cell volume regulation. Cell Physiol Biochem 2011, 28:1191-1202.

4. Gamsjaeger R, Liew CK, Loughlin FE, Crossley M, Mackay JP: Sticky fingers: zinc-fingers as protein-recognition motifs. Trends Biochem Sci 2007, 32:63-70.

5. Emerson $\mathrm{RO}$, Thomas $\mathrm{JH}$ : Adaptive evolution in zinc finger transcription factors. PLoS Genet 2009, 5:e1000325.

6. Luo K, Yuan J, Shan Y, Li J, Xu M, Cui Y, Tang W, Wan B, Zhang N, Wu Y, Yu L: Activation of transcriptional activities of AP1 and SRE by a novel zinc finger protein ZNF445. Gene 2006, 367:89-100.

7. Sekimata M, Takahashi A, Murakami-Sekimata A, Homma Y: Involvement of a novel zinc finger protein, MIZF, in transcriptional repression by interacting with a methyl-CpG-binding protein, MBD2. J Biol Chem 2001, 276:42632-42638

8. Zhang W, Bleibel WK, Roe CA, Cox NJ, Eileen Dolan M: Gender-specific differences in expression in human lymphoblastoid cell lines. Pharmacogenet Genomics 2007, 17:447-450.

9. Colombo J, Fachel AA, De Freitas Calmon M, Cury PM, Fukuyama EE, Tajara EH, Cordeiro JA, Verjovski-Almeida S, Reis EM, Rahal P: Gene expression profiling reveals molecular marker candidates of laryngeal squamous cell carcinoma. Oncol Rep 2009, 21:649-663.

10. Cheng L, Wang P, Yang S, Yang Y, Zhang Q, Zhang W, Xiao H, Gao H: Identification of genes with a correlation between copy number and expression in gastric cancer. BMC Med Genomics 2012, 5:14.

11. Belbin TJ, Singh B, Barber I, Socci N, Wenig B, Smith R, Prystowsky MB, Childs G: Molecular classification of head and neck squamous cell carcinoma using cDNA microarrays. Cancer Res 2002, 62:1184-1190.

12. Gonzalez HE, Gujrati M, Frederick M, Henderson Y, Arumugam J, Spring PW, Mitsudo K, Kim HW, Clayman GL: Identification of 9 genes differentially expressed in head and neck squamous cell carcinoma. Arch Otolaryngol Head Neck Surg 2003, 129:754-759.

13. Sok JC, Kuriakose MA, Mahajan VB, Pearlman AN, DeLacure MD, Chen FA: Tissue-specific gene expression of head and neck squamous cell carcinoma in vivo by complementary DNA microarray analysis. Arch Otolaryngol Head Neck Surg 2003, 129:760-770.

14. Belbin TJ, Singh B, Smith RV, Socci ND, Wreesmann VB, Sanchez-Carbayo M, Masterson J, Patel S, Cordon-Cardo C, Prystowsky MB, Childs G: Molecular profiling of tumor progression in head and neck cancer. Arch Otolaryngol Head Neck Surg 2005, 131:10-18.

15. Alevizos I, Mahadevappa M, Zhang X, Ohyama H, Kohno Y, Posner M, Gallagher GT, Varvares M, Cohen D, Kim D, et al: Oral cancer in vivo gene expression profiling assisted by laser capture microdissection and microarray analysis. Oncogene 2001, 20:6196-6204.

16. Messina DN, Glasscock J, Gish W, Lovett M: An ORFeome-based analysis of human transcription factor genes and the construction of a microarray to interrogate their expression. Genome Res 2004, 14:2041-2047.

17. Negi S, Imanishi M, Matsumoto $M$, Sugiura $Y$ : New redesigned zinc-finger proteins: design strategy and its application. Chemistry 2008, 14:3236-3249.

18. Sreerama N, Venyaminov SY, Woody RW: Estimation of protein secondary structure from circular dichroism spectra: inclusion of denatured proteins with native proteins in the analysis. Anal Biochem 2000, 287:243-251.

19. Sali A, Blundell TL: Comparative protein modelling by satisfaction of spatial restraints. J Mol Biol 1993, 234:779-815.

20. Sali A, Potterton L, Yuan F, van Vlijmen H, Karplus M: Evaluation of comparative protein modeling by MODELLER. Proteins 1995, 23:318-326.

21. Laskowski RA, Macarthur MW, Moss DS, Thornton JM: Procheck - a Program to Check the Stereochemical Quality of Protein Structures. J Appl Crystallogr 1993, 26:283-291.

22. Kabsch W, Sander C: Dictionary of protein secondary structure: pattern recognition of hydrogen-bonded and geometrical features. Biopolymers 1983, 22:2577-2637.

23. Wang Y, Ye X, Zhou J, Wan Y, Xie H, Deng Y, Yan Y, Li Y, Fan X, Yuan W, et al: A novel human KRAB-related zinc finger gene ZNF425 inhibits mitogen-activated protein kinase signaling pathway. BMB Rep 2011, 44:58-63.

24. Whitmore L, Woollett B, Miles AJ, Klose DP, Janes RW, Wallace BA: PCDDB: the Protein Circular Dichroism Data Bank, a repository for circular dichroism spectral and metadata. Nucleic Acids Res 2011, 39:D480-486. 
25. Canduri F, de Azevedo WF: Protein crystallography in drug discovery. Curr Drug Targets 2008, 9:1048-1053.

26. Carvalho AL, Trincao J, Romao MJ: X-ray crystallography in drug discovery. Methods Mol Biol 2009, 572:31-56.

27. Blancafort P, Segal DJ, Barbas CF 3rd: Designing transcription factor architectures for drug discovery. Mol Pharmacol 2004, 66:1361-1371.

28. Crotty JW, Etzkorn C, Barbas CF 3rd, Segal DJ, Horton NC: Crystallization and preliminary X-ray crystallographic analysis of Aart, a designed sixfinger zinc-finger peptide, bound to DNA. Acta Crystallogr Sect F Struct Biol Cryst Commun 2005, 61:573-576.

29. Li FY, Papworth M, Minczuk M, Rohde C, Zhang YY, Ragozin S, Jeltsch A: Chimeric DNA methyltransferases target DNA methylation to specific DNA sequences and repress expression of target genes. Nucleic Acids Res 2007, 35:100-112.

30. Reynolds L, Ullman C, Moore M, Isalan M, West MJ, Clapham P, Klug A, Choo Y: Repression of the HIV-1 5' LTR promoter and inhibition of HIV-1 replication by using engineered zinc-finger transcription factors. Proc Natl Acad Sci USA 2003, 100:1615-1620.

31. Segal DJ, Goncalves J, Eberhardy S, Swan CH, Torbett BE, Li X, Barbas CF 3rd: Attenuation of HIV-1 replication in primary human cells with a designed zinc finger transcription factor. J Biol Chem 2004, 279:14509-14519.

32. Mino T, Hatono T, Matsumoto N, Mori T, Mineta Y, Aoyama Y, Sera T: Inhibition of DNA replication of human papillomavirus by artificial zinc finger proteins. J Virol 2006, 80:5405-5412.

33. Brooks BR, Bruccoleri RE, Olafson BD, States DJ, Swaminathan S, Karplus M: Charmm - a Program for Macromolecular Energy, Minimization, and Dynamics Calculations. J Comput Chem 1983, 4:187-217.

34. Braun W, Go N: Calculation of protein conformations by proton-proton distance constraints. A new efficient algorithm. J Mol Biol 1985, 186:611-626.

doi:10.1186/1480-9222-15-10

Cite this article as: Colombo et al:: Expression, purification and molecular analysis of the human ZNF706 protein. Biological Procedures Online 2013 15:10.

\section{Submit your next manuscript to BioMed Central and take full advantage of:}

- Convenient online submission

- Thorough peer review

- No space constraints or color figure charges

- Immediate publication on acceptance

- Inclusion in PubMed, CAS, Scopus and Google Scholar

- Research which is freely available for redistribution 